\title{
BMC
}

Plant Biology

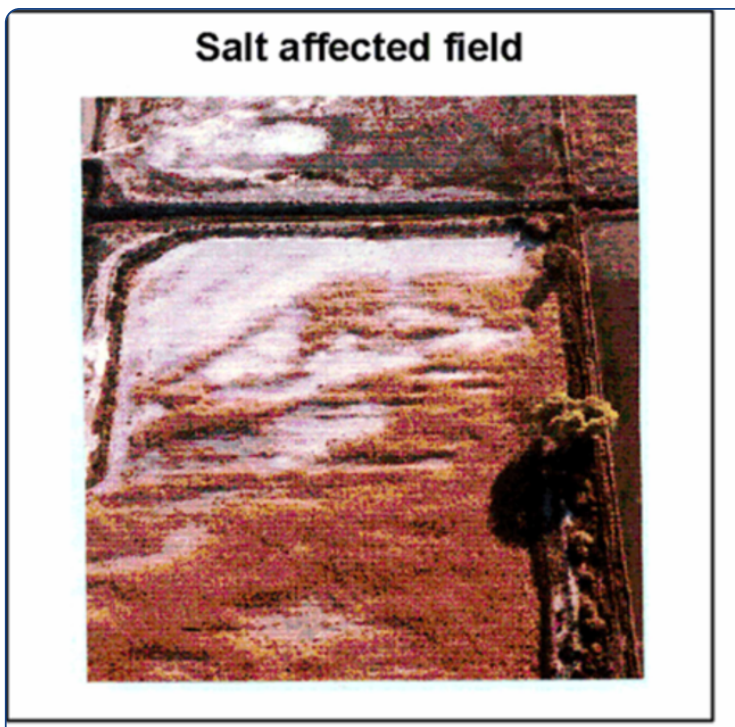

http://ag.arizona.edu/research/schumaker/images/figures/figure-1.gif

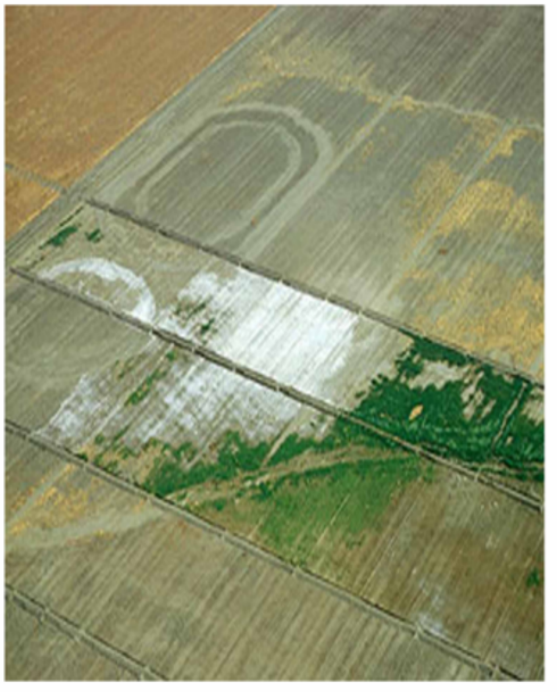

http://www.learner.org/courses/envsci/unit/text.php?unit=8\&secNum=7

\section{Growth attenuation under saline stress is mediated by the heterotrimeric $\mathrm{G}$ protein complex}

Colaneri et al. 


\title{
Growth attenuation under saline stress is mediated by the heterotrimeric $\mathrm{G}$ protein complex
}

\author{
Alejandro C Colaneri ${ }^{1}$, Meral Tunc-Ozdemir ${ }^{1}$, Jian Ping Huang ${ }^{1}$ and Alan M Jones ${ }^{1,2^{*}}$
}

\begin{abstract}
Background: Plant growth is plastic, able to rapidly adjust to fluctuation in environmental conditions such as drought and salinity. Due to long-term irrigation use in agricultural systems, soil salinity is increasing; consequently crop yield is adversely affected. It is known that salt tolerance is a quantitative trait supported by genes affecting ion homeostasis, ion transport, ion compartmentalization and ion selectivity. Less is known about pathways connecting $\mathrm{NaCl}$ and cell proliferation and cell death. Plant growth and cell proliferation is, in part, controlled by the concerted activity of the heterotrimeric G-protein complex with glucose. Prompted by the abundance of stress-related, functional annotations of genes encoding proteins that interact with core components of the Arabidopsis heterotrimeric G protein complex (AtRGS1, AtGPA1, AGB1, and AGG), we tested the hypothesis that G proteins modulate plant growth under salt stress.

Results: $\mathrm{Na}^{+}$activates $\mathrm{G}$ signaling as quantitated by internalization of Arabidopsis Regulator of $\mathrm{G}$ Signaling protein 1 (AtRGS1). Despite being components of a singular signaling complex loss of the G $\beta$ subunit (agb1-2 mutant) conferred accelerated senescence and aborted development in the presence of $\mathrm{Na}^{+}$, whereas loss of AtRGS1 (rgs 1-2 mutant) conferred $\mathrm{Na}^{+}$tolerance evident as less attenuated shoot growth and senescence. Site-directed changes in the $\mathrm{Ga}$ and $\mathrm{G} \beta \gamma$ protein-protein interface were made to disrupt the interaction between the Ga and GBY subunits in order to elevate free activated Ga subunit and free G $\beta \gamma$ dimer at the plasma membrane. These mutations conferred sodium tolerance. Glucose in the growth media improved the survival under salt stress in Col but not in agb1-2 or rgs 1-2 mutants.

Conclusions: These results demonstrate a direct role for G-protein signaling in the plant growth response to salt stress. The contrasting phenotypes of agb1-2 and rgs 1-2 mutants suggest that G-proteins balance growth and death under salt stress. The phenotypes of the loss-of-function mutations prompted the model that during salt stress, $G$ activation promotes growth and attenuates senescence probably by releasing ER stress.
\end{abstract}

\section{Background}

Three hundred million hectares are irrigated worldwide. Secondary salinization of soils has become a major undesirable consequence of this agronomic activity. With a greater need to increase crop yield on less productive land, a better knowledge of the physiological basis of salt tolerance will facilitate the engineering of salt tolerant crops needed to meet the near future food demand [1-5].

$\mathrm{NaCl}$ is the most soluble, widespread, and abundant of the salts in soils. As low as $40 \mathrm{mM} \mathrm{NaCl}$ generates an

\footnotetext{
* Correspondence: alan_jones@unc.edu

'Department of Biology, University of North Carolina at Chapel Hill, Chapel Hill NC, 27599, USA

${ }^{2}$ Department of Pharmacology, University of North Carolina at Chapel Hill, Chapel Hill, NC, 27599, USA
}

osmotic pressure of $0.2 \mathrm{MPa}$ and this stress manifests invariably as shoot growth arrest and senescence in most glycophytes $[4,6]$. Tolerance to salinity is commonly reflected in plant growth, which varies as the response progresses, and each phase of the adaptation may involve different signaling pathways [7]. It is generally accepted that this response is biphasic comprised of a growth attenuating osmotic phase followed by a toxic ionic phase $[4,6]$. The increased concentration of cytoplasmic sodium disrupts $\mathrm{K}^{+}$homeostasis, affects general trans-membrane transport, and competes with $\mathrm{Mg}^{2+}$ at the active site of many different enzymes, thus impairing metabolism $[4,8,9]$ manifesting as reduced cell division/ expansion and increased senescence.

Despite progress in understanding the phenomenon of plant salt-tolerance, the molecular basis for sensing and 
responding to extracellular $\mathrm{Na}^{+}$remains controversial $[10,11]$. It is generally accepted that $\mathrm{Na}^{+}$sensing occurs via the Salt Overly Sensitive (SOS) pathway [12]. Signaling is initiated in the cytoplasm by the SOS2/ SOS3 calcium-responsive protein kinase pathway and transduced to the plasma membrane to regulate the $\mathrm{Na}^{+} / \mathrm{H}^{+}$antiporter (SOS1) and reinstate ionic homeostasis. However, there is still a poor understanding about the role of the plasma membrane (PM) in sensing and signaling in response to $\mathrm{Na}^{+}[8,13]$.

Arguably, the best understood plasma membrane signaling pathway is mediated by the heterotrimeric $\mathrm{G}$ protein complex [14-21]. In Arabidopsis, this complex is comprised minimally of a G $\alpha$ subunit, a G $\beta \gamma$ dimer and a 7-transmembrane (7TM) Regulator of G Signaling (RGS) protein (AtGPA1, AGB1, AGG, AtRGS1). Genetic evidence supports a role for this $G$ protein complex in glucosestimulated cell proliferation and plant growth [22-32].

In animals, a $\mathrm{G}$ protein-coupled receptor (GPCR) catalyzes nucleotide exchange (GTP for GDP) on the G $\alpha$ subunit, leading to $G$ activation. In plants, the $G \alpha$ subunit spontaneously exchanges GDP for GTP without the requirement of a GPCR $[33,34]$. Therefore, to regulate $\mathrm{G}$ protein activity, most plants use a cell surface, 7-TMRGS protein, the prototype being AtRGS1 [24]. AtRGS1 keeps the complex in the inactive state. Sustained activation of G signaling involves physically uncoupling AtRGS1 from the $\mathrm{G}$ protein complex to allow spontaneous nucleotide exchange and release of the $\mathrm{G} \beta \gamma$ dimer. The cell accomplishes this uncoupling by endocytosis of AtRGS1 whereby AtRGS1 cycles through the endosome while the GTP-bound AtGPA1 remains on the plasma membrane [17]. Few G protein-interacting elements that lie downstream of the activation step are known [35-38] and none of the classic $\mathrm{G}$ protein targets from animals are found in plants [39].

Toward obtaining these downstream elements in plants, a $G$ protein interactome was generated to assemble the set of plant-specific effectors using yeast complementation assays [40]. This $a b$ initio assembled G-protein interactome contains 544 interactions between 434 proteins (http:// bioinfolab.unl.edu/emlab/Gsignal/index.pl). Among the various biological functions assigned to the 434 G-protein interactors, the response to salt stress function is overrepresented. Heterotrimeric G-protein signaling is indirectly linked with the salt response in plants other than Arabidopsis. For example, over-expression of $\mathrm{G} \alpha$ or $\mathrm{G} \beta$ genes obtained from Pisum sativum confers increased tolerance to salt in transgenic tobacco [41]. In rice, the steady-state levels of transcripts encoding the $\mathrm{G \alpha}$ and $\mathrm{G \gamma}$ subunits are dramatically elevated by $\mathrm{NaCl}$ but not $\mathrm{KCl}[42,43]$. Indirect links between salt response and G-signaling can also be deduced for Arabidopsis. Ablation of AtWNK8 kinase, a key regulator of G signaling
[28,44], strengthens tolerance to salt an osmotic stress [45]. GPA1 and AGB1 mediate ABA modulation of stomata aperture during stress $[19,46]$. Attenuation of growth and increased cell death by drought or salt is attributed, in part, to ER stress $[47,48]$. In Arabidopsis, ABG1 regulates the UPR through an unknown pathway [49].

Here, we show that in response to $\mathrm{Na}^{+}$, AtRGS internalizes which is a robust indicator that the G-protein is activated. As predicted from our functional analysis of G-protein interactors, genetic disruption of the G-signaling system results in plants with altered adaptation to salt stress. Loss of the G $\beta y$ dimer (AGB1) confers hypersensitivity while loss of AtRGS1 confers hyposensitivity to $\mathrm{Na}^{+}$. We propose a mechanism to balance growth and senescence under salt stress.

\section{Results}

The $\mathrm{G}$ protein interactome suggests a role for $\mathrm{G}$ proteins in saline stress

Additional file 1: Data Set S1, shows that the "response to abiotic stimulus", "response to stress", and "metabolic process" are the top 5 most enriched GO terms for G protein interactors. A quarter of the detected plant-G-protein interactors were annotated as abiotic stimulus responsive proteins, and half are annotated as metabolism. Additional file 1: Data Set S1 is rank-ordered by p-values, consequently the top terms represent broader general annotations with less information. We used the information contained in the resulting directed acyclic graph (DAG) [50] to systematize the selection of the most informative terms that are significantly enriched among interactors (Additional file 2: Figure S1). Table 1 shows the 22 terms found at the terminal branches of the DAG, all of them were found enriched with a corrected p-value $<0.005$. By focusing on the terminal nodes, the annotations provided a clearer picture of the potential biological functions governed by G-proteins and their interactors.

Table 1 reveals a combination of biotic and abiotic stress responses with central metabolic processes. This suggests that a network of $G$ protein interactors integrates nutrient availability with stress sensing to modulate growth and survival. Proteins with roles in osmotic and salt stress responses occupied one tenth of the G-interactome, and were enriched with the highest statistical support (Additional file 2: Figure S1, Table 1).

\section{$\mathrm{Na}^{+}$activates plant $\mathrm{G}$ signaling}

Our functional profile analysis for the G-protein interactome suggested that $\mathrm{G}$ proteins mediate $\mathrm{NaCl}$ responses. To test this hypothesis, we transplanted 5-d-old Arabidopsis seedlings of the different genotypes from $1 / 4$ MS agar plates to $1 / 4$ MS agar plates supplemented with $200 \mathrm{mM}$ $\mathrm{NaCl}$. Arabidopsis seedlings lacking the $\mathrm{G} \beta$ subunit of the heterotrimeric G protein complex (agb1-2) rapidly 
Table 1 The G-protein interactome is enriched with proteins annotated to response to salt stress

\begin{tabular}{|c|c|c|c|c|c|c|c|c|}
\hline GO term & Description & P-value & $\mathrm{BH}^{*} \mathrm{p}$-value & Enrichment & $\mathrm{N}$ & B & $\mathbf{n}$ & b \\
\hline GO:0046686 & response to cadmium ion & $5.48 \mathrm{E}-12$ & $1.24 \mathrm{E}-09$ & 4.59 & 27460 & 448 & 401 & 30 \\
\hline GO:0009651 & response to salt stress & $3.49 \mathrm{E}-11$ & $6.43 \mathrm{E}-09$ & 3.47 & 27460 & 750 & 401 & 38 \\
\hline GO:0006970 & response to osmotic stress & $6.62 \mathrm{E}-11$ & $1.12 \mathrm{E}-08$ & 3.33 & 27460 & 803 & 401 & 39 \\
\hline GO:0010200 & response to chitin & $6.53 \mathrm{E}-10$ & $9.13 \mathrm{E}-08$ & 4.28 & 27460 & 416 & 401 & 26 \\
\hline GO:0006612 & protein targeting to membrane & 4.73E-09 & $4.92 \mathrm{E}-07$ & 4.35 & 27460 & 362 & 401 & 23 \\
\hline GO:0010363 & regulation of plant-type hypersensitive response & 2.07E-08 & $1.91 \mathrm{E}-06$ & 4.18 & 27460 & 360 & 401 & 22 \\
\hline GO:0009416 & response to light stimulus & $2.64 \mathrm{E}-08$ & $2.38 \mathrm{E}-06$ & 2.57 & 27460 & 1120 & 401 & 42 \\
\hline GO:0009863 & salicylic acid mediated signaling pathway & $3.45 \mathrm{E}-08$ & $3.04 \mathrm{E}-06$ & 4.24 & 27460 & 339 & 401 & 21 \\
\hline GO:0009620 & response to fungus & $5.31 \mathrm{E}-08$ & $3.85 \mathrm{E}-06$ & 3.68 & 27460 & 446 & 401 & 24 \\
\hline GO:0006006 & glucose metabolic process & 7.79E-08 & $5.36 \mathrm{E}-06$ & 3.49 & 27460 & 490 & 401 & 25 \\
\hline GO:0006096 & glycolysis & $5.96 \mathrm{E}-07$ & $3.10 \mathrm{E}-05$ & 5.21 & 27460 & 184 & 401 & 14 \\
\hline GO:0009409 & response to cold & 1.05E-06 & $5.12 \mathrm{E}-05$ & 2.96 & 27460 & 602 & 401 & 26 \\
\hline GO:0009755 & hormone-mediated signaling pathway & $1.12 \mathrm{E}-06$ & $5.41 \mathrm{E}-05$ & 2.81 & 27460 & 683 & 401 & 28 \\
\hline GO:0009611 & response to wounding & $1.40 \mathrm{E}-06$ & $6.51 \mathrm{E}-05$ & 3.84 & 27460 & 321 & 401 & 18 \\
\hline GO:0031323 & regulation of cellular metabolic process & $1.82 \mathrm{E}-06$ & $8.28 \mathrm{E}-05$ & 1.84 & 27460 & 2347 & 401 & 63 \\
\hline GO:0006796 & phosphate-containing compound metabolic process & $1.94 \mathrm{E}-06$ & $8.66 \mathrm{E}-05$ & 2.14 & 27460 & 1410 & 401 & 44 \\
\hline GO:0050832 & defense response to fungus & $1.98 \mathrm{E}-06$ & $8.73 \mathrm{E}-05$ & 3.75 & 27460 & 329 & 401 & 18 \\
\hline GO:0006094 & gluconeogenesis & 3.63E-06 & 1.47E-04 & 5.23 & 27460 & 157 & 401 & 12 \\
\hline GO:0019684 & photosynthesis, light reaction & 4.65E-06 & $1.78 \mathrm{E}-04$ & 6.28 & 27460 & 109 & 401 & 10 \\
\hline GO:0000097 & sulfur amino acid biosynthetic process & $5.78 \mathrm{E}-06$ & 2.15E-04 & 3.82 & 27460 & 287 & 401 & 16 \\
\hline GO:0006412 & translation & $7.18 \mathrm{E}-06$ & $2.60 \mathrm{E}-04$ & 3.57 & 27460 & 326 & 401 & 17 \\
\hline GO:0006725 & cellular aromatic compound metabolic process & $9.76 \mathrm{E}-06$ & 3.47E-04 & 1.66 & 27460 & 3012 & 401 & 73 \\
\hline
\end{tabular}

*BH: multiple testing correction for $\mathrm{p}$ values (Benjamini and Hochberg method [51]).

The table includes GO terms found in the terminals nodes of each branch in the directed acyclic graph. These nodes contain the most specific and informative annotations that resulted significantly enriched.

Enrichment $=(b / n) /(B / N)$ where $N$ is the total number of genes associated to any GO term, B is the total number of genes associated with a specific GO term, $\mathrm{n}$ is the number of genes in the analyzed set, and $\mathrm{b}$ is the number of genes in the analyzed set associated to a particular $\mathrm{GO}$ term.

senesced (Figure 1A) compared to the wild-type. agb1-2 seedlings became bleached of chlorophyll while Col-0 seedlings displayed typical stress symptoms such as high levels of anthocyanin (Figure 1A) but did not bleach. This prompted the hypothesis that $\mathrm{NaCl}$ itself directly or indirectly activates $\mathrm{G}$ signaling to promote stress survival. To test activation, plants expressing AtRGS1-YFP were treated with $\mathrm{NaCl}$ or $\mathrm{KCl}$ and AtRGS1-YFP internalization was quantitated. AtRGS1 internalization is a standard reporter for $\mathrm{G}$ protein activation [28]. $\mathrm{NaCl}$, but not $\mathrm{KCl}$, initiated G signaling indicating activation is caused by $\mathrm{Na}^{+}$not $\mathrm{Cl}^{-}$ (Figure 1B and $\mathrm{C}$ ). Proteins visualized in the endosome after $\mathrm{NaCl}$ treatment had a plasma membrane origin since blocking new synthesis of protein had no effect on the subcellular location after treatment (Figure 1C).

AtRGS and AGB1, components of the same G protein complex, have antagonistic roles in the survival of Arabidopsis to salt stress

Plants lacking AtRGS1 (rgs1-2) or the G $\beta$ subunit (agb12 ), which is required for activation of G-signaling [28], showed clear differences in shoot growth when germinated and grown on $1 / 4$ MS agar media supplemented with $\mathrm{NaCl}$ (Figure 2). Attenuation of shoot growth and hastening of leaf senescence are well-characterized phenotypes displayed by plants grown under saline stress. Compared with Col-0, agb1-2 seedlings on $\mathrm{NaCl}$ were small and chlorotic. In contrast, rgs1-2 mutants were larger and less chlorotic than Col-0. The accelerated senescence observed in agb1-2 seedlings growing in $\mathrm{NaCl}$-supplemented agar plates was also observed when plants were grown on soil (Figure 2B). agb1-2 mutants showed clear chlorotic lesions in older leaves possibly due to higher accumulation of $\mathrm{Na}^{+}$in this tissue.

Arabidopsis is a glycophyte. At moderate salt concentration (e.g. $50 \mathrm{mM}$ ), growth is already noticeably affected and at $100 \mathrm{mM} \mathrm{NaCl}$ growth is severely inhibited. As clearly evident with the hypersensitive agb1-2 genotype, plant development is arrested and almost all the seedlings die at early stages (Figure 2C, 2D and Additional file 3: Figure S2). The differential sensitivities between Col0, agb1-2 and rgsl-2 were tested under 

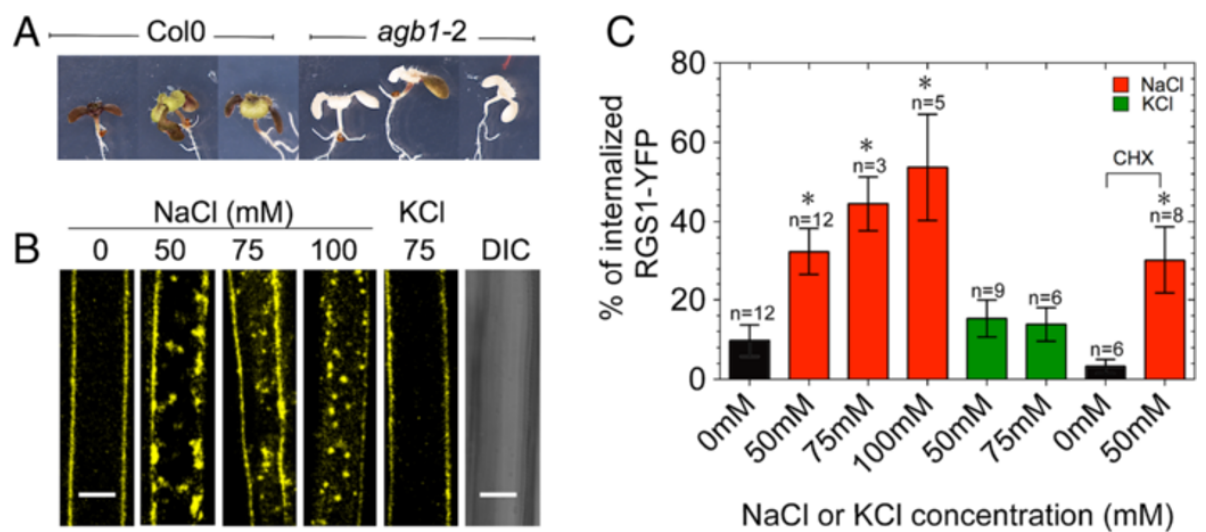

\section{$\mathrm{NaCl}$ or $\mathrm{KCl}$ concentration (mM)}

Figure $1 \mathrm{Na}^{+}$triggers AtRGS1-YFP endocytosis. A) 5-d-old agb1-2 and Col-0 seedlings that were grown on 1/4 MS agar plates were then transplanted to $1 / 4 \mathrm{MS}$ agar plates supplemented with $200 \mathrm{mM} \mathrm{NaCl}$. Images were captured over time, but shown are seedlings $5 \mathrm{~d}$ after initiation of the treatment (i.e. 10-d-old). B) AtRGS1-YFP endocytosis in Arabidopsis hypocotyl epidermal cells after treatment with various concentrations of $\mathrm{NaCl}$ or $\mathrm{KCl}$ for $16 \mathrm{~h}$. Differential interference contrast (DIC) shows no change in cell integrity after $16 \mathrm{~h}$ of $100 \mathrm{mM} \mathrm{NaCl}$ treatment. The DIC is image of the same hypocotyl shown for the $100 \mathrm{mM} \mathrm{NaCl}$ treatment. C) AtRGS1 internalization was quantified after $16 \mathrm{~h}$ treatment at the indicated NaCl concentrations. CHX: seedlings were incubated with $70 \mu \mathrm{m}$ cyclohexamide followed by water (control) or $50 \mathrm{mM} \mathrm{NaCl}$ treatment for $16 \mathrm{~h}$. Error bars represent standard deviation, $n=$ replicates. Pair wise comparisons between the means were performed with a T-test confidence level (CL) of 95\%. All pair-wise comparisons included their respective control (no salt). ${ }^{*}$, means (treatment and control) differ significantly ( $p$ value $<0.05$ ). Scale bars $=10 \mu \mathrm{m}$.

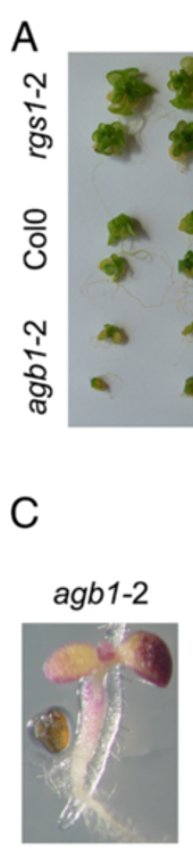

arrested seedling

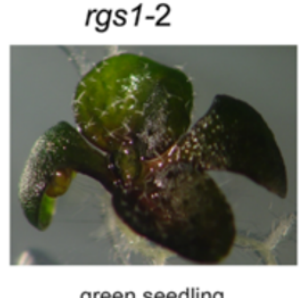

green seedling
B

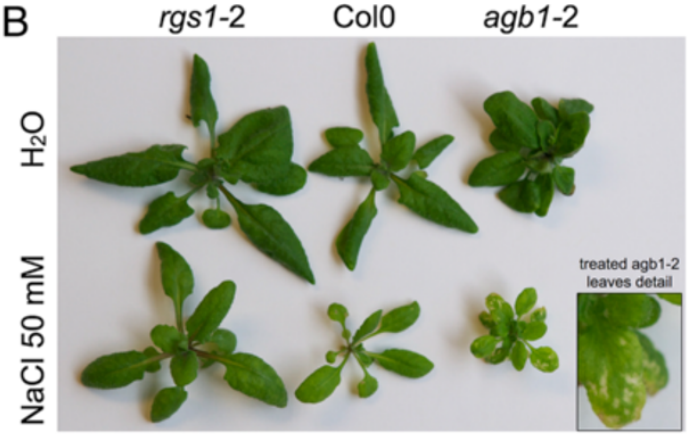

$\mathrm{D}$

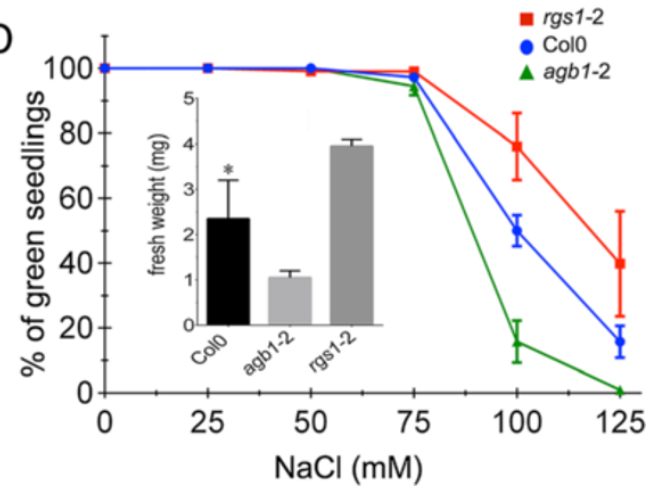

Figure 2 G-protein mutants have altered responses to saline stress. A) Col-0, rgs 1-2 and agb1-2 seeds were germinated (note: they were not transplanted as in Figure 1) and seedlings grown on $1 / 4 \mathrm{MS}$ agar media supplemented with $50 \mathrm{mM} \mathrm{NaCl}$ (see Materials and Methods for this distinction in protocols). Images were captured 2 weeks after germination. B) Seedlings were grown on Turface Quick Dry ${ }^{\mathrm{m}}$ pretreated with $1 / 4$ MS liquid media and irrigated with $50 \mathrm{mM} \mathrm{NaCl}$ solution. C) Examples of an arrested and a green seedling after $10 \mathrm{~d}$ in $1 / 4 \mathrm{MS}$ media supplemented with $125 \mathrm{mM} \mathrm{NaCl}$ D) Col-0, rgs1-2 and agb1-2 seeds were germinated and grown on 1/4 MS agar media supplemented with different concentrations of $\mathrm{NaCl}$. Green seedlings were scored $10 \mathrm{~d}$ after germination. Error bars represent the SEM calculated from replicate experiments- Col is statistically different from agb1-2 and rgs1-2 with a confidence level of 95\% ( $p$ value $=0.0053, \mathrm{CL} 95 \%$ ). 
different concentrations of $\mathrm{NaCl}$ (Figure 2D). The greatest difference among the genotypes was at $100 \mathrm{mM} \mathrm{NaCl}$. The ability of $100 \mathrm{mM} \mathrm{NaCl}$ to arrest development was used to develop a "greening assay" to quantitate the salt-induced phenotypes of G-protein mutants (Additional file 3: Figure S2). Green seedlings that were not arrested were scored and the percent indicated for each treatment. rgs1-2 mutants had fewer arrested seedlings compared to Col-0, in contrast to agb1-2 seedlings which were almost all arrested (Additional file 3: Figure S2). These effects were not observed with the same concentration of $\mathrm{KCl}$ indicating that the observed phenotype is $\mathrm{Na}^{+}$sodium specific (data not shown). An osmotic response is ruled out since an equal osmotic pressure applied with mannitol had no effect on shoots of the different genotypes tested (Additional file 4: Figure S3).

Seedlings lacking the G $\alpha$ subunit (gpa1-4) behaved similarly to rgs 1 null mutants (Figure 3) consistent with AtRGS1 signaling operating through its cognate $\mathrm{G} \alpha$ subunit (t-test, $\mathrm{p}$-value $=0.02$, CL 95\%). It also suggests that the primary signaling element is the $G \beta \gamma$ dimer since loss of either AtRGS1 or AtGPA1 increases the pool size

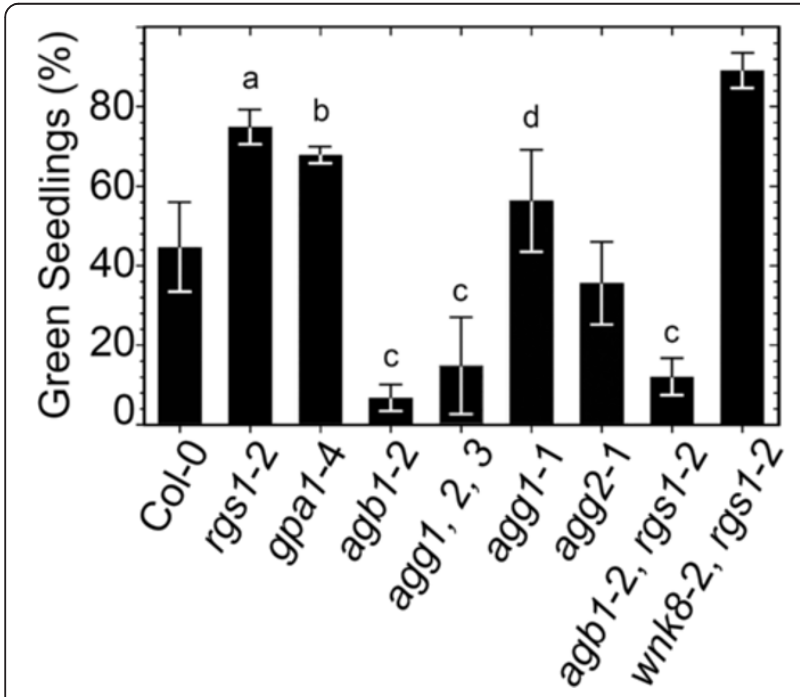

Figure 3 Genetic characterization of G-protein signaling under hypersaline/hyperosmotic stress. Arabidopsis seeds from each genotype were germinated and seedlings grown on 1/4 MS agar media supplemented with $100 \mathrm{mM} \mathrm{NaCl}$. Green seedlings were counted $10 \mathrm{~d}$ after germination. Error bars represent the standard deviation calculated from triplicates. Pair wise comparisons between the means were done with t-tests at a confidence level $(\mathrm{CL})$ of $90 \%$ and 95\%. "a" indicates that the mean for rgs $1-2$ differs from Col-0 or rgs 1-2/agb1-2 double mutant (CL 95\%, p-values $=0.002$ and 0.005 respectively). "b" indicates gpa 1-4 and Col 0 have different means ( $C L$ 95\%, p-value $=0.02$ ). Results are representative of three different experiments. " $c$ " indicates that the means of these genotypes were compared with all the other genotypes and always resulted in statistical significant differences between them and all other genotypes not denoted with " $c$ " at a CL of 95\% ( $p$ value $<0.05$ ). " $d$ " indicates that agg1-1 and agg2-1 have different means ( $C L$ 90\%, p-value $=0.051)$. of freed G $\beta \gamma$ dimer at the plasma membrane. As expected, when all three of the $\mathrm{G} \gamma$ subunits are genetically deleted thus removing AGB1 from the plasma membrane, plants had the agb1-2 phenotype. Loss of either AGG1 or AGG2 had little or no effect suggesting functional redundancy or that AGB1 dimers comprised with AGG1 or AGG2 are not involved in the $\mathrm{Na}$ + response. The agb1-2 allele was epistatic to the rgs1-2 allele consistent with AGB1 acting downstream of AtRGS1 (Figure 3). Like rgs1-2 mutants, fewer gpa 1-4 seedlings were arrested on $100 \mathrm{mM} \mathrm{NaCl}$ compared to Col-0, however they were $30 \%$ smaller than rgs1-2 (t-test, $\mathrm{p}$-value $=0.0005$, confidence level $=$ 95\%), thus the gpa1 "salt" phenotype is not exactly like the rgs1 phenotype.

Endocytosis of AtRGS1 causes sustained activation of the $G \alpha$ subunit and the $G \beta \gamma$ dimer at the plasma membrane and this process requires phosphorylation by WNK8 kinase [28]. Interestingly, mammalian homologs of plant WNK8 regulate $\mathrm{Na}^{+} / \mathrm{K}^{+}$channel activity through a signaling phosphorylation pathway involving oxidative stress responsive kinases [52]. Zhang and coworkers reported that loss of WNK8 conferred salt tolerance [45]. Since WNK8 is required for AtRGS1 endocytosis, we expected that combining loss-offunction mutations in both AtRGS1 and WNK8 would be epistatic. However, loss of both AtRGS1 and WNK8 (rgs1-2/wnk8-2) conferred slightly more $\mathrm{NaCl}$ tolerance than the rgs1-2 allele alone suggesting a small additive effect (Figure 3).

\section{Elevating active, plasma membrane AtGPA1 subunit and} AGB1/AGG dimer conferred salt tolerance

To test whether AtRGS1 operates through the Ga subunit to regulate the activity of the $G \beta \gamma$ dimer, we used two point mutations that independently disrupt binding between AtGPA1 and AGB1 and consequently increase the pool of activated $G$ proteins at the plasma membrane [53]. Disrupting heterotrimer formation is expected to increase the pool of active $G \alpha$ and $G \beta \gamma$ subunits without disrupting AtRGS1 function. Mutant AGB1 proteins were expressed in the agb1-2 null background and at least two independent lines were characterized. Both $\mathrm{W}_{109}$ and $\mathrm{S}_{129}$ residues lie within the $G \alpha-G \beta$ protein interface and mutation of these residues to alanine prevents $G \alpha$ binding to $G \beta \gamma$ without disruption of the plasma membrane localization [53]. Reduced heterotrimer formation means an increase in activated $G \alpha$ subunit and G $\beta \gamma$ dimer at the plasma membrane. Mutations in these residues confer $\mathrm{NaCl}$ tolerance (Figure 4). The positive control was a set of mutations on the surface located outside the G $\alpha-G \beta$ surface of interaction $\left(\mathrm{R}_{25} \mathrm{~A}, \mathrm{E}_{248} \mathrm{~K}\right.$ double). This mutant AGB1 rescued the agb1-2 null mutant to wild type levels of tolerance. The negative control was a set of mutations 


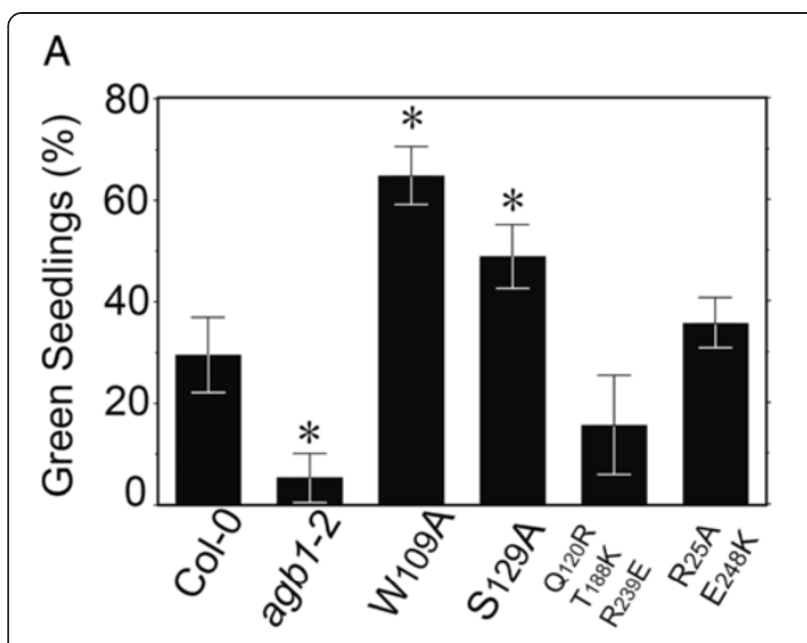

B

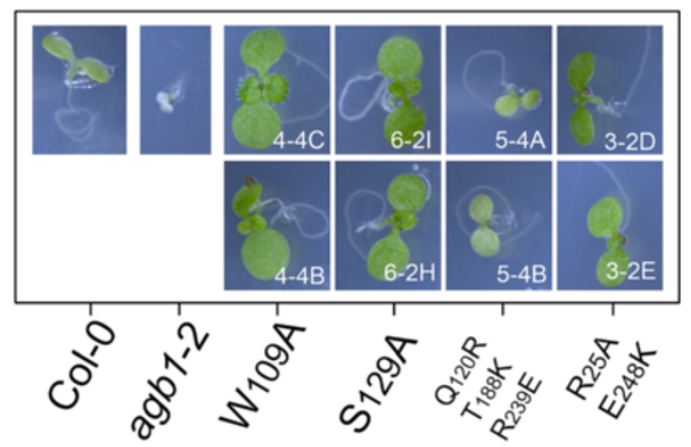

Figure 4 Promoting the active state of $\mathrm{G}$ signaling by disfavoring heterotrimer formation confers salt tolerance. Col-0, agb1-2, and Arabidopsis seedlings overexpressing (35S promoter) mutated versions of the AGB1 gene in the agb1-2 background were germinated and grown in $1 / 4 \mathrm{MS}$ plates supplement with $100 \mathrm{mM} \mathrm{NaCl}$.

A) Green seedlings were scored $10 \mathrm{~d}$ after germination. Mutants are indicated with the wild-type residue position and substitution. Mutations W109A and S129A both lie in the Ga:GßY protein interface and thus shift the equilibrium away from heterotrimer formation to active Ga subunit and GBy dimer. Data is expressed as the mean of 3 replicates with 36 seedlings per genotype per plate; error bars = SD. Pair wise comparisons between the means of Col 0 plants complemented with mutant variants of the AGB1 genes were performed with a single-tailed T-test. ${ }^{*}$, means comparison show up as statistically significant. The agb1-2 null mutation conferred reduced number of green seedling $(C L=99 \%, p$ value 0.0009). Plants complemented with the W109A or S129A variants of the AGB1 gene produced higher number of green seedlings, $(C L=99 \%$, $p$ value 0.0042 and $C L=90 \%$, $p$ value 0.07 ), respectively). B) Images of seedling were taken at the end of the treatment. Two lines for agb1-2 seedling complemented with mutated AGB1 are shown.

in a surface patch $\left(\mathrm{Q}_{120} \mathrm{R}, \mathrm{T}_{188} \mathrm{~K}, \mathrm{R}_{239} \mathrm{E}\right.$ triple mutant) known to be involved in many cellular responses [53]. This mutant AGB1 did not rescue the agb1-2 salt-sensitive phenotype.

\section{$\mathrm{G}$ signaling mediates glucose-induced tolerance to $\mathrm{NaCl}$} A regulatory signaling network integrating environmental cues with nutritional status may play a key role in shunting energy from developmental-linked biosynthetic metabolism into metabolic pathways aimed at boosting stress tolerance [54]. Since both AtRGS1 and AGB1 are part of a sugar-dependent signaling pathway and corresponding mutants have altered responsiveness to $\mathrm{NaCl}$, we tested if sugar sensing was a factor of the $\mathrm{NaCl}$ response. Sucrose (Figure 5A) and glucose (Figure 5B, $\mathrm{p}$ value $=0.064$, CL 90\%), improved salt tolerance for Col0 seedlings. Glucose had no effect on salt tolerance for rgs1-2 or agb1-2 mutants (t-test, $\mathrm{p}$ value $=0.27$ and $\mathrm{p}$ value $=0.49, \mathrm{CL} 90 \%)$ at the tested concentration .

\section{Discussion}

Geng et al. [7] elegantly showed that the reaction of a root to salt is complex and has dynamics in both temporal and spatial dimensions. Upon an initial shock to applied salt, the root growth rate dramatically decreases within the first few hours (designated the stop phase) followed by a slow constant growth rate over the next few hours (quiescent phase). During the next $\sim 10$ hours, growth recovers (recovery phase) albeit not to the full rate of the control roots and then growth reaches a new steady-state rate (homeostasis phase). This implies a complex and dynamic regulatory system. Indeed, Geng, et al. [7] showed that throughout this timeline different transcriptional programs begin and end in a tissuespecific context.

Given the delay in activation (Figure 1), G proteins are most likely to be involved in the recovery phase but the mechanism is unclear and at this juncture, we can only speculate based on the observations that we and others report. In many plants, the 7TM-RGS protein holds the Ga subunit loaded with GDP in an inactive state, which favors the formation of the inactive heterotrimer (Ga:G $\beta \gamma)$. Because plant $\mathrm{G} \alpha$ subunits spontaneously exchange GDP for GTP, in the absence of the 7TM-RGS, the G $\alpha$ subunit is GTP bound (i.e. activated) and the G $\beta \gamma$ dimer is freed. Sustained activation of $\mathrm{G}$ signaling involves physically uncoupling 7TM-RGS from the $G$ protein complex to allow spontaneous nucleotide exchange and release of the $\mathrm{G} \beta \gamma$ dimer. The cell accomplishes this physical uncoupling by endocytosis of the 7TM-RGS whereby it cycles through the endosome while the GTP-bound G $\alpha$ subunit remains on the plasma membrane [17]. It is abundantly clear that endocytosis of AtRGS1 increases the active G protein pool [44]. Upon activation, the GTP-bound $G \alpha$ subunit releases the $G \beta \gamma$ dimer enabling both $G$ protein components to interact with cellular targets. The Go subunit is a positive modulator of cell proliferation in Arabidopsis [22,27] and the GBy dimer, among other roles it plays, operates in the UPR, which is important for cell survival during ER stress $[49,55]$. Salt induces the UPR in which case the UPR alleviates $\mathrm{NaCl}$ stress by increasing ER-associated protein degradation [56]. Failure to do so triggers salt-associated-cell- 

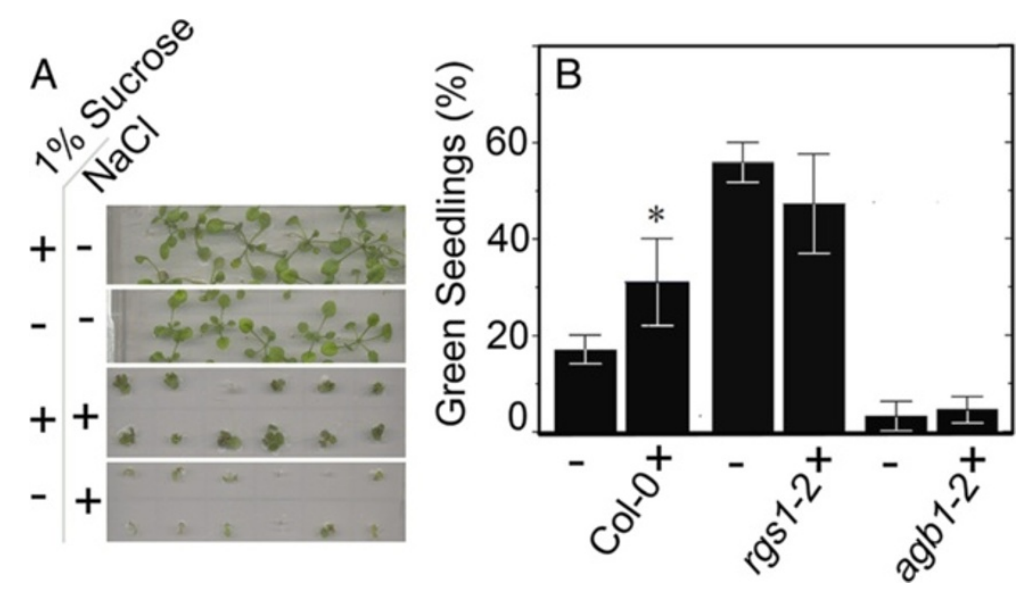

Figure 5 Sugar ameliorates the salt stress. A) Col-0, seeds were germinated and seedlings grown on 1/4 MS agar media supplemented with or without $100 \mathrm{mM} \mathrm{NaCl}$ and with or without 1\% sucrose. Seedlings shown are 3 weeks old. B) Col-0, rgs 1-2 and agb1-2 seed were germinated and seedlings grown on 1/4 MS agar media supplemented with $100 \mathrm{mM} \mathrm{NaCl}$ plus (+) or minus (-) $0.5 \%$ glucose. Green seedlings were scored $10 \mathrm{~d}$ after germination. Error bar represents the STDev from 3 replicates. Each genotype treated with glucose was compared to its no glucose control. *means statistically different with a P value $=0.01$.

death [47]. AGB1 plays a positive role in the UPR response [49], since three tested loss-of-function agb1 mutants showed hypersensitivity to tunicamycin (note that an earlier report by Wang et al. [55] describing the opposite $a g b 1$ UPR phenotype could not be reproduced) [49].

The genetic data here support this biological context. In the rgs1-2 mutant, two important activities are increased at the plasma membrane: a proliferative factor (GTPbound AtGPA1) and an ER-stress reliever factor (unsequestered AGB1). Consequently, mutations that promote active $\mathrm{G} \alpha$ subunit and $\mathrm{G} \beta \gamma$ dimers confer sustained growth and tolerance to $\mathrm{NaCl}$ compared to WT. Consistent with this idea, disruption of the heterotrimer in a way that promotes active AtGPA1 and AGB1 without the loss of AtRGS1 also conferred tolerance to $\mathrm{NaCl}$ compared to Col-0 (Figure 4). The gpa1-4 phenotype is also consistent with this conclusion; in the absence of AtGPA1, plants have more activated AGB1 at the plasma membrane as for loss of AtRGS1, therefore these mutants are less sensitive to the stress. However, gpa1 mutants lack the cell proliferation function, therefore they do not behave phenotypically exactly like $r g s 1$ mutants (Figure 3 ). In contrast, $a g b 1$ 2 and $a g b 1-2 / r g s 1-2$ double mutants lack G $\beta$ thus making these seedlings highly sensitive to the ER-stress imposed by $\mathrm{NaCl}$.

While it is possible that AtRGS1 senses $\mathrm{Na}^{+}$, we do not favor this view since the $\mathrm{NaCl}$ effect (Figure 1B) is slow, thus activation may be indirect through an increase in glucose by regulation of glucose metabolism enzymes leading to increased sugar levels. In fact, it was clearly demonstrated that $\mathrm{NaCl}$ increases sugar levels in root [57] and leaf cells [58]. This also explains the ameliorative effect of applied glucose on $\mathrm{NaCl}$ responsiveness (Figure 5).

\section{Conclusions}

Plant tolerance to $\mathrm{NaCl}$, in particular the recovery phase, involves the plasma membrane $G$ protein-mediated glucose-signaling pathway. The mechanism for survival to salt stress requires $\mathrm{G}$ protein activation by releasing freed $\mathrm{G} \alpha$ subunits and $\mathrm{G} \beta \gamma$ dimers. The discovery here of sodium-induced activation of $G$ signaling via AtRGS1 endocytosis, whether or not direct or indirect through increased glucose levels, raises further complexity involving feedback loops that will need to be addressed.

\section{Methods}

\section{Plant material and growth conditions}

All plants were the Col-0 ecotype: rgs1-2 [24]; agb1-2 [25]; gpa1-4. [59]; wnk8-2 [28]; agg1-1 [60]; agg2-1 [61]; agg3-1 [62]; and the series of point mutations on AGB1 [53]. The quality of seed stock was a major factor for variability during the $\mathrm{NaCl}$ greening assays. All seeds were harvested from plants grown together under identical conditions. To eliminate crowding effects seeds were plated on a grid $1 \mathrm{~cm}$ apart. Seeds were surface sterilized with $70 \%$ ethanol solution for $10 \mathrm{~min}$, and $95 \%$ ethanol solution stratified on plates at $4^{\circ} \mathrm{C}$, 48 h. Media was 1/4 Murashige and Skoog (Calsson Labs, Cat\# MSP01) and 1.5\% phytoagar (RPI Corp. Cat \# A203001000.0), supplemented or not with $\mathrm{NaCl}, \mathrm{KCl}$, mannitol, and/or sucrose. Plates were moved to a growth chamber under constant light conditions $\left(21^{\circ} \mathrm{C}, 60 \mu\right.$ mole $\left.\mathrm{m}^{-2} \mathrm{~s}^{-1}\right)$. Differences among genotypes in the time of the onset of yellowing were greatest at day 10 under these conditions.

It is important to note that germinating and growing these genotypes on media containing $\mathrm{NaCl}$ vs. transferring seedlings germinated and grown first on media lacking $\mathrm{NaCl}$ to media containing $\mathrm{NaCl}$ affects the phenotypic outcome (c.f. Figures $1 \mathrm{~A}$ and $2 \mathrm{~A}$ ). 


\section{Accessions}

AtRGS1, At3G26090; AtGPA1, At2G26300;AGB1, At4G34460; ATWNK8, At5G41990; AGG1, At3G63420; AGG2, At3G22942; AGG3, At5G20635; WNK8, At5g41990.

\section{Salt tolerance in soil}

Seeds were germinated on $1 / 4$ MS agar media for $7 \mathrm{~d}$. Seedlings were transplanted to pots containing Turface Quick Dry $^{\mathrm{mm}}$ (Turface Athletics, Buffalo Grove, IL) presoaked with $1 / 4$ MS liquid media. Plants were grown for $5 \mathrm{~d}$. Healthy looking plants of each genotype were selected as control or treatment. Plants under $\mathrm{NaCl}$ treatment were kept under constant irrigation with $50 \mathrm{mM}$ $\mathrm{NaCl}$ solution. Water was used as the control.

\section{Fresh weight determination}

Seedling shoots were detached from the roots and weighed on an analytical balance. When shoots were harvested and weighed in batches, they were kept during this period in a $100 \%$ humidity chamber until reading could be taken.

\section{AtRGS1 internalization}

Columbia-0 (Col-0) seedlings stably expressing AtRGS1YFP fusion protein under the control of $35 \mathrm{~S}$ cauliflower mosaic virus promoter were first grown for $5 \mathrm{~d}$ at dark in 1/4MS liquid media without glucose. Then media was replaced by $\mathrm{NaCl}$ or $\mathrm{KCl}$ solutions at different concentrations or just water as a control. After 16 hs of treatment in dark seedlings were observed under the microscope. Vertical optical sections (i.e. Z stacks acquired) of hypocotyl epidermal cells of dark-grown seedlings located approximately 3-4 $\mathrm{mm}$ from the cotyledon were captured using a Zeiss LSM710 confocal laser scanning microscope equipped with a $\mathrm{C}$-Apochromat $x$ $40 \mathrm{NA}=1.20$ water immersion objective. YFP was excited using the 514-nm line from an argon laser and its respective emission was detected at $526-569 \mathrm{~nm}$ by a photomultiplier detector. The images were analyzed by using the software Image $J$ [63] as described by Urano et al. [28]. In brief, randomly selected hypocotyl images from three or four whole $Z$-section image stacks of 3 to 5 independent experiments were selected for quantification. Fluorescence signals were subject to a minimum cutoff and the intensity was measured and subtracted from the total hypocotyl fluorescence. Statistical comparison of mean fluorescence signal was performed using Student $\mathrm{t}$ test.

\section{Statistical analysis}

\section{Gene ontology (GO) enrichment analysis}

Data was obtained from a $G$ protein interactome generated with a yeast complementation assays revealing the set of $\mathrm{G}$ protein plant-specific effectors [40]. This interactome is of high quality because the database was constructed of multiple screens of 9 cDNA libraries using wildtype and mutant forms of $\mathrm{G}$ protein baits. The G-protein interactome contains at least 544 interactions between at least 434 proteins (http://bioinfolab.unl.edu/ emlab/Gsignal/index.pl). This database was analyzed for gene functional annotation using Gene Ontology enRIchment anaLysis and visuaLizAtion tool (GOrilla) [64]. The DAG generated by this tool systematically establishes thresholds based on the structure of the results to reach informative GO terms. To build a background list, all the AGI codes representing the Arabidopsis genes were obtained from the TAIR web site. AGI codes were converted to official gene symbols using the gene ID conversion tool at DAVID Bioinformatics Resources 6.7 [65].

\section{Pair-wise comparison of means}

Unpaired Student t-test (two tailed) at a confidence level of $90 \%$ or $95 \%$ were performed with GraphPad Prism version 6.00 for windows (GraphPad Software, San Diego California USA, www.graphpad.com).

\section{Additional files}

Additional file 1: Data Set S1. GO enrichment analysis results (excel file). This data set contains the functional enrichment analysis results obtained with the list of genes encoding G-protein interactors [40]. A description of the column headers in Data Sets S1 is provided at the bottom of the spreadsheet.

Additional file 2: Figure S1. Directed acyclic graph (DAG) depicting the functional profile associated with the G-protein interactome. The picture is a simplified illustration of the entire dataset provided in Additional file 1: Data Set S1. Color code bar is the heat map reflecting the statistical support for each enriched $\mathrm{GO}$ term with corresponding color.

Additional file 3: Figure S2. Complete data acquisition for 3 replicate experiments. All the $\mathrm{NaCl}$ green seedling assays were done according to the format shown here. A) Col0, rgs 1-2 and agb1-2 sterilized seed were sown on squared plates with $1-\mathrm{cm}$ grid (1 seed per square). Plates contained $1 / 4$ MS salts supplemented with $100 \mathrm{mM} \mathrm{NaCl}$, or $1 / 4 \mathrm{MS}$ salts alone for controls (panel C). Seeds were stratified on plates at $4^{\circ} \mathrm{C}, 48 \mathrm{~h}$ Seeds were germinated and grown in constant light conditions $\left(60 \mu\right.$ mole $\left.\mathrm{m}^{-2} \mathrm{~s}^{-1}\right)$ at $21^{\circ} \mathrm{C}$. B) Green seedlings were scored $10 \mathrm{~d}$ after germination. The onset of yellowing (senescent seedlings vs. green tolerant seedlings) varied $\pm 2 \mathrm{~d}$ from experiment to experiment. Three replicates of genotypes, treatments and experiments were conducted. Error bars represent standard deviation of triplicates. C and D) Typical results found for seedlings (Col-0, rgs 1-2 and agb 1-2) after $10 \mathrm{~d}$ on control plates (1/4 MS, 0.8\% agar)

Additional file 4: Figure S3. Mannitol does not evoke the $\mathrm{NaCl}$ phenotypes in the tested genotypes. Experiments were performed as described for Figure S2 but the media was supplemented with 200 mM mannitol instead of $\mathrm{NaCl}$

\section{Abbreviations}

7TM: AGB1seven transmembrane; AtGPA1: Arabidopsis Ga subunit 1; AGB1: Arabidopsis G $\beta$ subunit 1; AtRGS1: Arabidopsis regulator of $G$ signaling protein 1; CL: Confidence level; ER: Endoplasmic reticulum; GPCR: G-proteincoupled receptor; mPa: Mega pascals; RGS: Regulator of G Signaling; UPR: Unfolded protein response; WNK: With no lysine kinase. 


\section{Competing interests}

The authors declare that they have no competing interests.

\section{Authors' contributions}

AC designed experiments characterizing the salt responsiveness of the genotypes described. AC also analyzed the G protein interactome for associations in annotations. MT-O designed and performed experiments testing salt-induced AtRGS1 endocytosis. J-PH assisted AC in some experiments and was involved in experimental design. AMJ and AC wrote the manuscript. AMJ managed the project. All authors read and approved the final manuscript.

\section{Acknowledgements}

This work was supported by grants from the NIGMS (R01GM065989) and NSF (MCB-0718202) to A.M.J and NIGMS (R01GM079271) to T.C.E. The Division of Chemical Sciences, Geosciences, and Biosciences, Office of Basic Energy Sciences of the US Department of Energy through the grant DE-FG02-05er15671 to A.M.J. funded technical support in this study.

Received: 21 January 2014 Accepted: 30 April 2014

Published: 12 May 2014

\section{References}

1. Agarwal PK, Shukla PS, Gupta K, Jha B: Bioengineering for salinity tolerance in plants: state of the art. Mol Biol 2012, 54:102-123.

2. Arzani A: Improving salinity tolerance in crop plants: a biotechnological view. Vitro Cell Develop Biol - Plant 2008, 44(5):373-383.

3. Jaggard KW, Qi A, Ober ES: Possible changes to arable crop yields by 2050. Philos Trans R Soc Lond B Bio/ Sci 2010, 365(1554):2835-2851.

4. Munns R, Tester M: Mechanisms of salinity tolerance. Annu Rev Plant Biol 2008, 59:651-681.

5. Sanchez DH, Pieckenstain FL, Szymanski J, Erban A, Bromke M, Hannah MA Kraemer U, Kopka J, Udvardi MK: Comparative functional genomics of salt stress in related model and cultivated plants identifies and overcomes limitations to translational genomics. PLoS One 2011, 6:e17094.

6. Hasegawa P, Bressan R, Zhu J-K, Bohnert H: Plant cellular and molecular responses to high salinity. Annu Rev Plant Physiol Plant Mol Biol 2000, 51:463-499.

7. Geng Y, Wu R, Wee CW, Xie F, Wei X, Chan PMY, Tham C, Duan L, Dinneny JR: A spatio-temporal understanding of growth regulation during the salt stress response in Arabidopsis. Plant Cell 2013, 25:2132-2154.

8. Conde A, Chaves MM, Gerós H: Membrane transport, sensing and signaling in plant adaptation to environmental stress. Plant Cell Physio 2011, 52:1583-1602.

9. Hill CB, Jha D, Bacic A, Tester M, Roessner U: Characterization of ion contents and metabolic responses to salt stress of different Arabidopsis AtHKT1;1 Genotypes and their parental strains. Mol Plant 2013, 6:350-368.

10. Bertorello A, Zhu J-K: SIK1/SOS2 networks: decoding sodium signals via calcium-responsive protein kinase pathways. Pflugers Arch - Eur J Physio 2009, 458:613-619.

11. Zhang J, Jia W, Yang J, Ismail A: Role of ABA in integrating plant responses to drought and salt stresses. Field Crop Res 2006, 97:111-119.

12. Ji H, Pardo JM, Batelli G, Van Oosten MJ, Bressan RA, Li X: The Salt Overly Sensitive (SOS) pathway: established and emerging roles. Mol Plant 2013, 6:275-286

13. Maathuis FJM: Sodium in plants: perception, signalling, and regulation of sodium fluxes. J Exp Bot 2014, 65:849-858.

14. Okamoto H, Gobel C, Capper RG, Saunders N, Feussner I, Knight MR: The alpha-subunit of the heterotrimeric $\mathrm{G}$-protein affects jasmonate responses in Arabidopsis thaliana. J Exp Bot 2009, 60:1991-2003.

15. Trusov Y, Sewelam N, Rookes JE, Kunkel M, Nowak E, Schenk PM, Botella JR: Heterotrimeric $G$ proteins-mediated resistance to necrotrophic pathogens includes mechanisms independent of salicylic acid-, jasmonic acid/ ethylene- and abscisic acid-mediated defense signaling. Plant J 2009 58:69-81.

16. Alvarez S, Hicks LM, Pandey S: ABA-dependent and -independent G-protein signaling in Arabidopsis roots revealed through an iTRAQ proteomics approach. J Proteome Res 2011, 10:3107-3122.

17. Urano D, Chen J-G, Botella JR, Jones AM: Heterotrimeric G protein signalling in the plant kingdom. Open Biol 2013, 3(3):120186.
18. Wang $X Q$, Ullah $H$, Jones $A M$, Assmann SM: $G$ protein regulation of ion channels and abscisic acid signaling in Arabidopsis guard cells. Science 2001, 292:2070-2072.

19. Fan LM, Zhang W, Chen JG, Taylor JP, Jones AM, Assmann SM: Abscisic acid regulation of guard-cell $\mathrm{K}+$ and anion channels in Gbeta- and RGS deficient Arabidopsis lines. Proc Natl Acad Sci U S A 2008, 105:8476-8481.

20. Joo JH, Wang S, Chen JG, Jones AM, Fedoroff NV: Different signaling and cell death roles of heterotrimeric $\mathrm{G}$ protein alpha and beta subunits in the Arabidopsis oxidative stress response to ozone. Plant Cell 2005, 17:957-970.

21. Bhardwaj D, Sheikh AH, Sinha AK, Tuteja N: Stress induced beta subunit of heterotrimeric G-proteins from Pisum sativum interacts with mitogen activated protein kinase. Plant Signal Behav 2011, 6:287-292.

22. Chen J-G, Gao Y, Jones AM: Differential roles of Arabidopsis heterotrimeric G-protein subunits in modulating cell division in roots. Plant Physiol 2006 141:887-897.

23. Chen J-G, Jones AM: AtRGS1 function in Arabidopsis thaliana. Meth Enzymol 2004, 389:338-350.

24. Chen J-G, Willard FS, Huang J, Liang J, Chasse SA, Jones AM, Siderovski DP: A seven-transmembrane RGS protein that modulates plant cell proliferation. Science 2003, 301:1728-1731

25. Ullah H, Chen J-G, Temple B, Boyes DC, Alonso JM, Davis KR, Ecker JR, Jones AM: The $b$ subunit of the Arabidopsis $G$ protein negatively regulates auxin-induced cell division and affects multiple developmental processes. Plant Cell 2003, 15:393-409.

26. Ullah $\mathrm{H}$, Chen J-G, Wang S, Jones AM: Role of $\mathrm{G}$ protein in regulation of Arabidopsis seed germination. Plant Physio/ 2002, 129:897-907.

27. Ullah H, Chen J-G, Young J, Im K-H, Sussman MR, Jones AM: Modulation of cell proliferation by heterotrimeric G protein in Arabidopsis. Science 2001, 292:2066-2069.

28. Urano D, Phan N, Jones JC, Yang J, Huang J, Grigston J, Philip Taylor J, Jones AM: Endocytosis of the seven-transmembrane RGS1 protein activates G-protein-coupled signalling in Arabidopsis. Nat Cell Biol 2012, 14:1079-1088.

29. Wang HX, Perdue T, Weerasinghe R, Taylor JP, Cakmakci NG, Marzluff WF, Jones AM: A golgi hexose transporter is involved in heterotrimeric $\mathrm{G}$ protein regulated early development in Arabidopsis. Mol Biol Cell 2006, 17:4257-4269

30. Bommert $\mathrm{P}$, Je BI, Goldshmidt A, Jackson D: The maize Galpha gene COMPACT PLANT2 functions in CLAVATA signalling to control shoot meristem size. Nature 2013, 502:555-558.

31. Tsugama D, Liu S, Takano T: Arabidopsis heterotrimeric $\mathrm{G}$ protein beta subunit, $A G B 1$, regulates brassinosteroid signalling independently of BZR1. J Exp Bot 2013, 64:3213-3223.

32. Utsunomiya $Y$, Samejima C, Takayanagi $Y$, Izawa $Y$, Yoshida T, Sawada $Y$, Fujisawa $Y$, Kato $H$, Iwasaki $Y$ : Suppression of the rice heterotrimeric $G$ protein beta-subunit gene, RGB1, causes dwarfism and browning of internodes and lamina joint regions. Plant J 2011, 67:907-916.

33. Johnston CA, Taylor JP, Gao Y, Kimple AJ, Grigston JC, Chen J-G, Siderovski DP, Jones AM, Willard FS: GTPase acceleration as the rate-limiting step in Arabidopsis G protein-coupled sugar signaling. Proc Natl Acad Sci 2007, 104(44):17317-17322.

34. Urano D, Jones JC, Wang H, Matthews M, Bradford W, Bennetzen JL, Jones AM: G Protein Activation without a GEF in the Plant Kingdom. PLoS Genet 2012, 8(6):e1002756.

35. Friedman EJ, Wang HX, Perovic I, Deshpande A, Pochapsky TC, Temple BRS, Hicks SN, Harden TK, Jones AM: ACI-REDUCTONE DIOXYGENASE 1 (ARD1) is an effector of the heterotrimeric $\mathrm{G}$ protein beta subunit in Arabidopsis. J Biol Chem 2011, 286:30107-30118.

36. Huang J, Taylor JP, Chen J-G, Uhrig JF, Schnell DJ, Nakagawa T, Korth KL, Jones AM: The plastid protein THYLAKOID FORMATION1 and the plasma membrane G-protein GPA1 interact in a novel sugar-signaling mechanism in Arabidopsis. Plant Cell 2006, 18:1226-1238.

37. Mudgil Y, Uhrig JF, Zhou J, Temple B, Jiang K, Jones AM: Arabidopsis N-MYC DOWNREGULATED-LIKE1, a positive regulator of auxin transport in a G protein-mediated pathway. Plant Cell 2009, 21:3591-3609.

38. Warpeha KM, Upadhyay S, Yeh J, Adamiak J, Hawkins SI, Lapik YR Anderson MB, Kaufman LS: The GCR1, GPA1, PRN1, NF-Y signal chain mediates both blue light and abscisic acid responses in Arabidopsis. Plant Physiol 2007, 143:1590-1600.

39. Jones AM, Assmann SM: Plants: the latest model system for G-protein research. EMBO Rep 2004, 5:572-578. 
40. Klopffleisch K, Phan N, Augustin K, Bayne RS, Booker KS, Botella JR, Carpita NC, Carr T, Chen J-G, Cooke TR, Frick-Cheng A, Friedman EJ, Fulk B, Hahn MG, Jiang K, Jorda L, Kruppe L, Liu C, Lorek J, McCann MC, Molina A, Moriyama EN, Mukhtar MS, Mudgil Y, Pattathil S, Schwarz J, Seta S, Tan M, Temp U, Trusov Y, Urano D, Welte B, Yang J, Panstruga R, Uhrig J, Jones AM: Arabidopsis G-protein interactome reveals connections to cell wall carbohydrates and morphogenesis. Mol Syst Biol 2011, 7:532.

41. Misra S, Wu Y, Venkataraman G, Sopory S, Tuteja N: Heterotrimeric G-protein complex and G-protein-coupled receptor from a legume (Pisum sativum): role in salinity and heat stress and cross-talk with phospholipase C. Plant J 2007, 51:656-669.

42. Yadav D, Shukla D, Tuteja N: Rice heterotrimeric G-protein alpha subunit (RGA1): in silico analysis of the gene and promoter and its upregulation under abiotic stress. Plant Physiol Biochem 2013, 63:262-271.

43. Yadav DK, Islam SMS, Tuteja N: Rice heterotrimeric G-protein Gamma subunits (RGG1 and RGG2) are differentially regulated under abiotic stress. Plant Signal Behav 2012, 7:733-740.

44. Fu Y, Lim S, Urano D, Tunc-Ozdemir M, Phan N, Elston T, Jones A: Reciprocal encoding of signal intensity and duration in a glucose-sensing circuit. Cell 2014, 156:1084-1096.

45. Zhang B, Liu K, Zheng Y, Wang Y, Wang J, Liao H: Disruption of AtWNK8 enhances tolerance of Arabidopsis to salt and osmotic stresses via modulating proline content and activities of catalase and peroxidase. Int J Mol Sci 2013, 14:7032-7047.

46. Armstrong F, Leung J, Grabov A, Brearley J, Giraudat J, Blatt MR: Sensitivity to abscisic acid of guard-cell $\mathrm{K}+$ channels is suppressed by abi1-1, a mutant Arabidopsis gene encoding a putative protein phosphatase. Proc Natl Acad Sci U S A 1995, 92:9520-9524.

47. Liu L, Cui F, Li Q, Yin B, Zhang H, Lin B, Wu Y, Xia R, Tang S, Xie Q: The endoplasmic reticulum-associated degradation is necessary for plant salt tolerance. Cell Res 2011, 21:957-969.

48. Harb A, Krishnan A, Ambavaram MM, Pereira A: Molecular and physiological analysis of drought stress in Arabidopsis reveals early responses leading to acclimation in plant growth. Plant Physiol 2010, 154:1254-1271.

49. Chen $Y$, Brandizzi F: AtIRE1A/AtIRE1B and AGB1 independently control two essential unfolded protein response pathways in Arabidopsis. Plant $J$ 2012, 69:266-277.

50. Goeman JJ, Mansmann U: Multiple testing on the directed acyclic graph of gene ontology. Bioinformatics 2008, 24:537-544.

51. Benjaminin $Y$, Hochberg $Y$ : Controlling the false discovery rate: a practical and powerful approach to multiple testing. J Royal Stat Society Series B 1995, 57:289-300.

52. Sengupta S, Tu S-W, Wedin K, Earnest S, Stippec S, Luby-Phelps K, Cobb MH: Interactions with WNK (With No Lysine) family members regulate oxidative stress response 1 and ion co-transporter activity. J Biol Chem 2012, 287:37868-37879.

53. Jiang K, Frick-Cheng A, Trusov Y, Delgado-Cerezo M, Rosenthal DM, Lorek J, Panstruga R, Booker FL, Botella JR, Molina A, Ort DR, Jones AM: Dissecting Arabidopsis $\mathrm{G} \beta$ signal transduction on the protein surface. Plant Physiol 2012, 159:975-983.

54. Baena-González E: Energy signaling in the regulation of gene expression during stress. Mol Plant 2010, 3:300-313.

55. Wang S, Narendra S, Fedoroff N: Heterotrimeric G protein signaling in the Arabidopsis unfolded protein response. Proc Natl Acad Sci 2007, 104:3817-3822.

56. Liu J-X, Howell SH: Endoplasmic reticulum protein quality control and its relationship to environmental stress responses in plants. Plant Cell 2010, 22:2930-2942

57. Mišić D, Dragićević M, Šiler B, Nestorović Živković J, Maksimović V, Momčilović I, Nikolic M: Sugars and acid invertase mediate the physiological response of Schenkia spicata root cultures to salt stress. J Plant Physiol 2012, 169:1281-1289.

58. Wang X, Chang L, Wang B, Wang D, Li P, Wang L, Yi X, Huang Q, Peng M, Guo A: Comparative proteomics of Thellungiella halophila leaves from plants subjected to salinity reveals the importance of chloroplastic starch and soluble sugars in halophyte salt tolerance. Mol Cell Proteomics 2013, 12:2174-2195

59. Jones AM, Ecker JR, Chen JG: A re-evaluation of the role of the heterotrimeric $\mathrm{G}$ protein in coupling light responses in Arabidopsis. Plant Physio/ 2003, 131:1623-1627.
60. Mason MG, Botella JR: Completing the heterodimer: Isolation and characterization of an Arabidopsis thaliana G protein g-subunit cDNA. Proc Natl Acad Sci U S A 2000, 97:14784-14788.

61. Mason MG, Botella JR: Isolation of a novel G-protein $\gamma$-subunit from Arabidopsis thaliana and its interaction with $\mathrm{G} \beta(1)$. Biochim Biophys Acta 2001, 1520:147-153.

62. Chakravorty D, Trusov Y, Zhang W, Acharya BR, Sheahan MB, McCurdy DW, Assmann SM, Botella JR: An atypical heterotrimeric $G$ protein $\gamma$ subunit is involved in guard cell $\mathrm{K}+$ channel regulation and morphological development in Arabidopsis thaliana. Plant J 2011, 67:840-851.

63. Abramoff MD, Magalhaes PJ, Ram SJ: Image processing with ImageJ. Biophoton Internat 2004, 11:36-42.

64. Eden E, Navon R, Steinfeld I, Lipson D, Yakhini Z: GOrilla: a tool for discovery and visualization of enriched GO terms in ranked gene lists. BMC Bioinformatics 2009, 10:48.

65. Huang DW, Sherman BT, Lempicki RA: Systematic and integrative analysis of large gene lists using DAVID bioinformatics resources. Nat Protoc 2009, 4:44-57.

doi:10.1186/1471-2229-14-129

Cite this article as: Colaneri et al:: Growth attenuation under saline stress is mediated by the heterotrimeric $\mathrm{G}$ protein complex. BMC Plant Biology 2014 14:129.

\section{Submit your next manuscript to BioMed Central and take full advantage of:}

- Convenient online submission

- Thorough peer review

- No space constraints or color figure charges

- Immediate publication on acceptance

- Inclusion in PubMed, CAS, Scopus and Google Scholar

- Research which is freely available for redistribution
C BioMed Central 